\title{
The Impact of Problem Based Learning on Productive Skills and Attitude toward English Language Learning
}

\author{
Ni Wayan Vera Aryanti ${ }^{1}$, Luh Putu Artini ${ }^{2}$ \\ 1,2English Education Department \\ Ganesha University of Education \\ Singaraja Bali, Indonesia \\ 1putu.artini@undiksha.ac.id, ${ }^{2}$ nv_aryanti@yahoo.co.id
}

\begin{abstract}
This study aimed at analyzing the impact of Problem-based learning (PBL) on Students' productive skills and attitude toward English language learning (ELL). The study employed embedded mixed-method design which involved the collection of both quantitative and qualitative data. The data collection involved the use of pre-test, post-test, closed-ended questionnaire, open-ended questionnaire, observation checklist, and interview guide. Quantitatively, the data were analyzed by using Kolgomogorov-Smirnov formula to find the normality of the data and Paired Sample T-test to find the difference between students' productive skills and attitude before and after the treatment. Qualitatively, the data were analyzed by using Miles and Huberman data analysis which consists of data reduction, data display and conclusion drawing. The result of the study showed that there were significant impacts of PBL on students' productive skills and attitude toward ELL. This study also concluded that PBL gave positive impact on teaching and learning process.
\end{abstract}

Keywords: Problem-Based Learning, Productive Skill, Students, Attitude

\section{INTRODUCTION}

Problem-based learning (PBL) is a constructivist educational approach which guided by teachers who act as cognitive coaches [1,2]. Students develop their critical thinking, problem solving and collaborative skills as they identify problems, formulate hypotheses, conduct data searches, perform experiments, formulate solutions and determine the best solutions to the problem provided. Problem-based learning enables students to embrace complexity, find relevance and joy in their learning, and enhance their capacity for creative and responsible real-world problem solving.

According to Hmelo-Silver [3] problem-based learning is an instructional method centered on the learner. Thus, the students are required to be actively participated on the learning activity in the classroom. By doing their own work, the students are expected to be independent. Besides that, the students are subconsciously trained to be more creative in their task because they are challenged to try their own innovation.
Coffin [4] points out that in a problem based learning classroom, students are provided with a topic which they should develop through research or problem solving for their individual or group learning and teachers should monitor the project performed by students. It means that even though the students work individually, the teacher still should monitor the students' activity. The teacher directs the students by giving them topic to do in the class, so then the activity to be done by the students remain the main direction of the learning indicator or syllabus. Similarly, Problem-Based Learning is simply defined as an instructional model that contextualizes learning by presenting learners with problem to solve and product to develop [5].

Abidin [6] found that students who were educated by using Problem-Based learning achieved the learning goal successfully. In line with that, a research done by Othman \& Shah [7] also found a similar result that this particular learning model had a significant impact to the students' learning result. In addition, Torp and Sage [8] state that Problem-Based Learning also have several benefits for every subject matter such as: 1) Problem-Based Learning promotes self-motivation and self-responsibility to learn; 2) Problem-Based Learning facilitates more enjoyable and more effective learning; 3) Problem-Based Learning encourages learning from experience, allow the students to use and organize what have been learned to understand problems; 4) Problem-Based Learning integrates knowledge with practice; 5) ProblemBased Learning nurtures the ability to analyze problems and to identify and acquire knowledge and skills needed to deal with real-life-situations; 6) Problem-Based Learning develops teamwork and communication skills; 7) Problem-Based Learning train the students to be reflective and assess their own and others' work; 8) Problem-Based Learning cultivates independence, curiosity, and skills for self-directed, life-long learning.

Those studies reveal the significant effects of implementing Problem Based Learning Instruction on students' competence. The studies also show that PBL is an effective teaching model that can be used in the classroom. However, the research that particularly examine the impact of 
Problem Based Instruction on students' productive skills not much found. Similarly, research that particularly focus on the impact of PBL on students' attitude about learning EFL was hardly found. Thus, it is important investigating the impact Problem Based Learning Instruction on students' attitude toward English Language Learning. From those backgrounds, the aim of the study can be stated as follows: (1) analyzing the impact of Problem-Based Learning on students' English Productive skill (2) analyzing the impact of Problem-Based Learning on students' Attitude,

\section{METHODS}

This study applied embedded mixed method design by Creswell \& Clark [9]. The population of this study was Grade 8 students of SMP N 1 Kuta Utara which consists of 12 class and 412 students. The sample of the study was Grade $8 \mathrm{D}$ which consists of 36 students. The sample of the study was chosen randomly.

The research procedure involved (1) preliminary observation and interview, (2) try out of the instruments, (3) pre-test and questionnaire distribution, (4) treatment of Problem-Based Learning, (5) post-test and questionnaire distribution, and (6) data analysis.

The data collection involved the use of interview guide, observation checklist, productive skill pre-test and post-test, closed ended questionnaire, and open ended questionnaire. Interview guide was used to collect the data about teaching and learning practice applied by the teacher. There were two type of observation checklist used in this study. The first observation checklist contains the characteristic of ProblemBased Learning which was administered before the treatment given. It was used to observe if the class has applied ProblemBased Learning or not. The second checklist contains the step of Problem-Based Learning which was administered during the treatment. Pre-test and post-test were used to collect the data about students' productive skill. Close-ended and openended questionnaire were used to collect the data about students' attitude toward English Language Learning.

Quantitative data were analyzed by using Paired Sample T-test in order to find out the difference of students' attitude and students' productive skill. In order to apply Paired Sample T-test the data were required to be normally distributed thus normality test was also administered. Kolgomogorov-Smirnov formula by using SPSS 18.0 for windows was administered to find the normality of the data. Wilcoxson test was administered if the data were not normally distributed. The data which was analyzed quantitatively were speaking and writing pre-test and post-test and also closed ended questionnaire. Qualitative data was analyzed by using Miles and Huberman [10] data analysis which consist of data reduction, data display and conclusion drawing or verification. The data which analyzed qualitatively was open-ended questionnaire in order to find out students' attitude toward English Language Learning.

\section{RESULT AND DISCUSSION}

The Impact of PBL on Students' Productive skills

There were two skills examined in order to find the impact of Problem-Based Learning on students' productive skills, those are writing and speaking. Pre-test and post-test were administered in order to measure students' productive competence before and after the treatment of PBL. The result of the analysis can be seen in the following explanation.

\section{Writing}

Writing pre-test and post-test were conducted to reveal the impact of Project-Based Learning on students' writing skill. The students were assigned to do the same type of test from the pre-test and post-test. The test was an instructional test in which students were intended to develop a Descriptive Text based on the theme provided. The result of the writing pre test and post test can be seen in the table 1

\begin{tabular}{|c|c|c|c|}
\multicolumn{4}{|c}{ Table 1 Frequency of Writing Test } \\
\hline & $\begin{array}{c}\text { Mean } \\
\text { Score }\end{array}$ & $\begin{array}{c}\text { Below the } \\
\text { mean score }\end{array}$ & $\begin{array}{c}\text { Above the } \\
\text { mean score }\end{array}$ \\
\hline Pre Test & 72.19 & 20 & 16 \\
\hline Post Test & 80.67 & 15 & 21 \\
\hline
\end{tabular}

Based on the result of writing test before implementing Problem Based Learning in the classroom, it was obtained that the mean score of the writing was 72.19. Moreover, from 36 students in class $8 \mathrm{D}$ there were 20 students $(55.56 \%)$ who got score below the mean score. Meanwhile 16 students got score above the mean score $(44.44 \%)$. It means that there were more than half students in class 8D of SMPN 1 Kuta Utara who did not achieve the mean score.

The result of writing test indicated that students' writing achievement in the post test, with the average score of 80.67, was higher than pre-test. Moreover, from 36 students in class $8 \mathrm{D}$ there were 15 students $(41.67 \%)$ who got score below the mean score. Meanwhile, 21 students got score above the mean score $(58.33 \%)$.

The normality test was also done in order to know whether the obtained data were distributed normally or not. This test was administered by Kolmorogov-Smirnov formula by using SPSS 18.0 for windows. The criteria of the test used are the data can be categorized as normally distributed if the significance of the data is more than 0.05. the result of normality test of the questionnaire can be seen in the table 2 .

Table 2 The Normality Test of Writing Test

\begin{tabular}{|c|r|r|}
\hline & & \\
& $\begin{array}{c}\text { Pre-test_ } \\
\text { writing }\end{array}$ & $\begin{array}{c}\text { post_test_w } \\
\text { riting }\end{array}$ \\
\hline N & 36 & 36 \\
Normal Parameters ${ }^{\mathrm{a}, \mathrm{b}}$ & 72.19 & 80.67 \\
Mean & 5.176 & 4.414 \\
Std. Deviation & .136 & .123 \\
Most Extreme & .092 & .123 \\
Differences & -.136 & -.090 \\
Absolute & .818 & .736 \\
Positive & .515 & .651 \\
Negative & & \\
Kolmogorov-Smirnov Z & & \\
Asymp. Sig. (2-tailed) & & \\
\hline
\end{tabular}


For writing pre-test, the value of Kolmogorov-Smirnov statistic was .818 with significance score of .515 . For writing post-test data, the value of Kolmogorov-Smirnov statistic was .736 with significance score of .651 . both of those statistic showed that the significance of the statistics was higher than 0.05 , which can be said that the data were normally distributed.

The next step done after normality test was parametric test. Since the data were normally distributed, Paired T-test was conducted. The acceptation criteria of the significant effect were if the significance scores less than 0.05 . The result of the Paired T-test can be seen on the Table 3.

Table 3 Paired Samples Test Writing Test

\begin{tabular}{|c|c|c|c|c|}
\hline & \multirow{2}{*}{ Mean } & \multirow{2}{*}{$\begin{array}{c}\text { Std. } \\
\text { Deviation }\end{array}$} & \multirow{2}{*}{$\begin{array}{l}\text { Std. } \\
\text { Error } \\
\text { Mean }\end{array}$} & \\
\hline \multirow{2}{*}{$\begin{array}{c}\text { Pair 1 } \\
\text { pre_test_writing } \\
- \\
\text { post_test_writing }\end{array}$} & & & & \\
\hline & -3.472 & 1.320 & .220 & \\
\hline \multicolumn{2}{|c|}{$\begin{array}{l}\text { 95\% Confidence Interval of } \\
\text { the Difference }\end{array}$} & $\mathrm{t}$ & df & $\begin{array}{c}\text { Sig. } \\
(2- \\
\text { tailed) } \\
\end{array}$ \\
\hline Lower & Upper & & & \\
\hline-3.919 & -3.026 & -15.784 & 35 & .000 \\
\hline
\end{tabular}

From the data above, it can be seen that there was an improvement of students' writing test from the mean score 72.19 before the treatment become 80.67 after the treatment. Moreover, the significance of the effect of Problem Based Learning on students' writing skill was .000. If the standard of significance is 0.05 , it means that the significance data was less than the standard (sig. $=0.00<\alpha=0.05$ ). It can be concluded that there was a significant effect of Problem Based Learning on Students' writing skill of the eight grade students.

\section{Speaking}

In speaking there were two type of competences were being assessed, monologue and dialogue. In monologue test students were assigned to create and perform a simple monologue in form of recount individually. In dialogue test students were assigned to create and perform a dialogue which express offering, accepting, and refusing invitation. For dialogue test students did it with their partner.

\section{Monologue}

The speaking test was done in order to measure students speaking skill before and after the treatment given. In this study, the speaking skill was divided into two different type. Those were in form of monologue and dialogue. And the type of the test was speaking pre-test and post-test. For monologue pre-test and post-test, the students were given instruction to perform a monologue in form of recount text. The result of the speaking pre test and post test in form of monologue test can be seen in the table 4

Table 4 Frequency of Monologue Test

\begin{tabular}{|c|c|c|c|}
\hline & $\begin{array}{c}\text { Mean } \\
\text { Score }\end{array}$ & $\begin{array}{c}\text { Below the } \\
\text { mean score }\end{array}$ & $\begin{array}{c}\text { Above the } \\
\text { mean score }\end{array}$ \\
\hline Pre Test & 76.56 & 25 & 11 \\
\hline Post Test & 81.19 & 17 & 19 \\
\hline
\end{tabular}

Based on the result of monologue test, the score was higher in the pre-test, in which 81.19. Moreover, from 36 students in class $8 \mathrm{D}$ there were 17 students $(47.22 \%)$ who got score below the mean score. Meanwhile, 19 students got score above the mean score $(52.78 \%)$.

The normality test was also done in order to know whether the obtained data were distributed normally or not in monologue test. This test was administered by Kolmorogov-Smirnov formula by using SPSS 18.0 for windows. The criteria of the test used are the data can be categorized as normally distributed if the significance of the data is more than 0.05 . the result of normality test of the questionnaire can be seen in the table 5 .

Table 5 The Normality Test of Monologue Test

\begin{tabular}{|c|r|r|}
\hline & $\begin{array}{c}\text { pre_test_mon } \\
\text { ologue }\end{array}$ & $\begin{array}{c}\text { post_test_ } \\
\text { monologue }\end{array}$ \\
\hline $\mathrm{N}$ & 36 & 36 \\
Normal & 76.56 & 81.19 \\
Parameters & 3.791 & 3.311 \\
Mean & .104 & .152 \\
StDeviation & .104 & .085 \\
Most Extreme & -.091 & -.152 \\
Differences & .622 & .910 \\
Absolute & .834 & .379 \\
Positive & & \\
Negative & & \\
Kolmogorov- & & \\
Smirnov Z & & \\
Asymp. Sig. (2- & & \\
tailed) & & \\
\hline
\end{tabular}

For monologue pre-test, the value of KolmogorovSmirnov statistic was .622 with significance score of .834. For writing post-test data, the value of Kolmogorov-Smirnov statistic was .910 with significance score of .379 . Both of those statistic showed that the significance of the statistics was higher than 0.05 , which can be said that the data were normally distributed.

The next step done after normality test was parametric test. Since the data were normally distributed, Paired T-test was conducted. The acceptation criteria of the significant effect were if the significance scores less than 0.05 . The result of the Paired T-test can be seen on the Table 6.

\begin{tabular}{|c|c|c|c|c|}
\hline & \multirow[t]{2}{*}{ Mean } & \multirow{2}{*}{$\begin{array}{c}\text { Std. } \\
\text { Deviation }\end{array}$} & \multirow{2}{*}{$\begin{array}{l}\text { Std. } \\
\text { Error } \\
\text { Mean }\end{array}$} & \\
\hline \multirow{2}{*}{$\begin{array}{c}\text { Pair 1 } \\
\text { pre_test_monolog } \\
\text { ue - } \\
\text { post_test_monolog } \\
\text { ue }\end{array}$} & & & & \\
\hline & -4.639 & 1.988 & .331 & \\
\hline \multicolumn{2}{|c|}{$\begin{array}{l}\text { 95\% Confidence Interval of } \\
\text { the Difference }\end{array}$} & $\mathrm{t}$ & $\mathrm{df}$ & $\begin{array}{c}\text { Sig. } \\
(2- \\
\text { tailed) }\end{array}$ \\
\hline Lower & Upper & & & \\
\hline-5.311 & -3.966 & -14.002 & 35 & .000 \\
\hline
\end{tabular}

From the data above, it can be seen that there was an improvement of students' monologue test from the mean score 76.56 before the treatment become 81.19 after the treatment. Moreover, the significance of the effect of Problem Based 
Learning on students' speaking skill specifically monologue was .000 . If the standard of significance is 0.05 , it means that the significance data was less than the standard (sig. $=0.00<$ $\alpha=0.05$ ). It can be concluded that there was a significant effect of Problem Based Learning on Students' speaking skill specifically monologue of the eight grade students.

\section{Dialogue}

As well as students' speaking skill in presenting monologue, the students' dialogue performance was also taken into further analysis. For dialogue pre-test and post-test, the same type of test was given to them in pre-test and post-test. The test was in form of instruction in which the students were intended to perform dialogue with their partner in giving and responding to an invitation. The result of the Dialogue pre test and post test can be seen in the table 7 .

Table 7 Frequency of Dialogue Test

\begin{tabular}{|c|c|c|c|}
\hline & Mean Score & $\begin{array}{c}\text { Below the } \\
\text { mean score }\end{array}$ & $\begin{array}{c}\text { Above the } \\
\text { mean } \\
\text { score }\end{array}$ \\
\hline Pre Test & $\mathbf{7 6 . 6 4}$ & 23 & 13 \\
\hline $\begin{array}{c}\text { Post } \\
\text { Test }\end{array}$ & $\mathbf{8 0 . 8 9}$ & 16 & 20 \\
\hline
\end{tabular}

Based on the result of speaking test in form of dialogue before implementing Problem Based Learning in the classroom, it was obtained that the mean score of the writing was 76.64. Moreover, from 36 students in class 8D there were 23 students $(63.89 \%)$ who got score below the mean score. Meanwhile 13 students got score above the mean score $(36.11 \%)$. It means that there were more than half students in class $8 \mathrm{D}$ of SMPN 1 Kuta Utara did not achieve the mean score.

The normality test was done in order to know whether the obtained data were distributed normally or not. This test was administered by Kolmorogov-Smirnov formula by using SPSS 18.0 for windows. The criteria of the test used are the data can be categorized as normally distributed if the significance of the data is more than 0.05. The result of normality test of the questionnaire can be seen in the table 8 .

Table 8 The Normality Test of Dialogue Test

\begin{tabular}{|c|r|r|}
\hline \multicolumn{2}{|c|}{ Table 8 The Normality Test of Dialogue Test } \\
& & \\
& pre_test_dia & \\
& post_test_dial \\
& ogue \\
\hline logue & 36 & 36 \\
N & 76.64 & 80.89 \\
Normal Parameters ${ }^{\text {a,b }}$ & 3.296 & 2.906 \\
Mean & .155 & .204 \\
Std. Deviation & .098 & .114 \\
Most Extreme Differences & -.155 & -.204 \\
Absolute & .928 & 1.227 \\
Positive & .355 & .099 \\
Negative & & \\
\hline Kolmogorov-Smirnov Z & & \\
Asymp. Sig. (2-tailed) & & \\
& & \\
\hline
\end{tabular}

For Dialogue pre-test, the value of KolmogorovSmirnov statistic was .928 with significance score of .355. For writing post-test data, the value of Kolmogorov-Smirnov statistic was 1.227 with significance score of .099. Both of those statistic showed that the significance of the statistics was higher than 0.05 , which can be said that the data were normally distributed.

The next step done after normality test was parametric test. Since the data were normally distributed, Paired T-test was conducted. The acceptation criteria of the significant effect were if the significance scores less than 0.05 . The result of the Paired T-test can be seen on the Table 9 below.

Table 9 Paired Samples Test Dialogue Test

\begin{tabular}{|c|c|c|c|c|}
\hline & \multirow{2}{*}{ Mean } & \multirow{2}{*}{$\begin{array}{c}\text { Std. } \\
\text { Deviation }\end{array}$} & \multirow{2}{*}{$\begin{array}{c}\text { Std. } \\
\text { Error } \\
\text { Mean } \\
\end{array}$} & \\
\hline \multirow{2}{*}{$\begin{array}{c}\text { Pair 1 } \\
\text { pre_test_dialogue } \\
- \\
\text { post_test_dialogue }\end{array}$} & & & & \\
\hline & -4.250 & 2.285 & .381 & \\
\hline \multicolumn{2}{|c|}{$\begin{array}{l}\text { 95\% Confidence Interval of } \\
\text { the Difference }\end{array}$} & $\mathrm{t}$ & Df & $\begin{array}{l}\text { Sig. } \\
(2- \\
\text { tailed })\end{array}$ \\
\hline Lower & Upper & & & \\
\hline-5.023 & -3.477 & -11.160 & 35 & .000 \\
\hline
\end{tabular}

From the data above, it can be seen that there was an improvement of students' dialogue test from the mean score 76.64 before the treatment become 80.89 after the treatment. Moreover, the significance of the effect of Problem Based Learning on students' dialogue test was .000. If the standard of significance is 0.05 , it means that the significance data was less than the standard (sig. $=0.00<\alpha=0.05$ ).

Based on the result of the data, generally both of the monologue and dialogue had improved between its pre-test and post-test. The following table is provided in order to present some information about the difference between both pre-test and post-test. The data can be seen in table 10 .

Table 10 The Impact of Problem-Based Learning Towards Students' Speaking Skill

\begin{tabular}{|c|c|c|}
\hline \multirow{2}{*}{ Speaking } & \multicolumn{2}{|c|}{ Mean Score } \\
\cline { 2 - 3 } & Pre-Test & Post-Test \\
\hline Monologue & 76.56 & 81.19 \\
Dialogue & 76.64 & 80.89 \\
\hline Total Mean Score & 76.6 & 81.04 \\
\hline
\end{tabular}

In order to give complete information about the result of the data on the impact of Project-Based Learning toward students' English productive skills, the researcher also provided a table consists of the summary of pre-test and posttest result of English productive skills. The result is presented in table .11.

Table 11 The Impact of Problem-Based Learning Towards Students' English Productive Skills

\begin{tabular}{|c|c|c|}
\hline \multirow{2}{*}{$\begin{array}{c}\text { English Productive } \\
\text { Skills }\end{array}$} & \multicolumn{2}{|c|}{ Mean Score } \\
\cline { 2 - 3 } & Pre-Test & Post-Test \\
\hline Writing & 72.19 & 80.67 \\
\hline Speaking & 76.6 & 81.04 \\
\hline
\end{tabular}




\section{The Impact of PBL on Students'Attitude toward English Language Learning}

In order to see the difference between students attitude toward English Language Learning before and after given PBL treatment, close-ended and open ended questionnaire were distributed. The result of the data analysis can be seen in the following explanation.

Table 12 Result Close-Ended Questionnaire of Each Students' Attitude Types

\begin{tabular}{|c|c|c|}
\hline \multirow{2}{*}{ Aspect } & \multicolumn{2}{|c|}{ Criteria } \\
\cline { 2 - 3 } & Before Treatment & After Treatment \\
\hline Behavioral & 97.23 & 121.47 \\
\hline Cognitive & 88.22 & 118.42 \\
\hline Affective & 96.25 & 119.50 \\
\hline
\end{tabular}

The result of the data analysis shows that there was a significant differences between students' attitude before the treatment and after the treatment $(\mathrm{t}=-7.47$, and $\mathrm{P}=.000)$. The data indicates that the significance data was less than the standard $(\operatorname{sig}=.000<\alpha=.005)$.It can be concluded that there was a significant impact of Problem-Based Learning toward students' attitude.

In order to support the numeric data on the students' attitude toward English Language Learning in the form of description an open-ended questionnaire was also administered. Practically, similar with the close-ended questionnaire, the open-ended questionnaire was also distributed before and after treatment. The open-ended questionnaire itself was consisted in 3 questions which represented three types of students' attitude toward English Language Learning based on Wenden's theory namely behavioral, cognitive, and affective attitude.

The result of the open-ended questionnaire in term of students' behavioral attitude toward English Language Learning indicated there were 23 students responded negatively $(64.28 \%)$. From the description most of the students' responses indicated that the students had lack of volition to participate in the learning process they had done in the classroom. The other 3 students (7.14\%) responded neutrally by stating there was no typical behavior they had done during the learning process. Meanwhile, from 36 students, there were only 10 students $(28.58 \%)$ who responded positively by saying they were willing to do the activity done during the learning process. The findings indicate that more than half of the students were giving negative responses toward learning before the Problem-Based Learning implemented in the classroom. Furthermore, after ProblemBased Learning was implemented, the students' answers towards the learning showed to have better response. The result of the students' answer indicated that 33 students $(92.85 \%)$ had positive response on their behavior as the result of the happiness and excitement they got from doing the learning process. The other 3 students $(7.15 \%)$ responded neutrally and had no typical behavior in doing the learning.

Secondly, the result of the open-ended questionnaire in term of students' cognitive attitude found out that there were
20 students $(57.15 \%)$ responded to the learning negatively by stating that they faced some difficulties and felt weary as a result of monotonous activity during the learning process. Moreover, there were $9(25.00 \%)$ students felt no distinctive quality toward the material in learning process. However, only $8(17.85 \%)$ students who responded the questions positively. Their responses indicated that they were eager to learn because it was easy for them follow the activity such as doing task in the textbook and listening to the teacher's instruction. Meanwhile, after Problem-Based Learning was implemented in the classroom, the students' descriptive answers indicated that there were 25 positive response points from the students. From the description were known that the students could comprehend the knowledge well. Meanwhile, the other 9 students had no typical respond on the learning itself.

Thirdly, in term of students' affective, the result found that there were 23 students $(64.28 \%)$ responded negatively by implying that they were felt unhappy and bored toward the learning process as a result of unexciting activity. The other 3 students $(7.15 \%)$ indicated neutral response toward learning. The students' description represented that they had no particular willing toward the learning. Unfortunately, only 10 (28.57\%) students had positive response toward the learning itself by pointing out that they were happy to do simple activity in the classroom. Meanwhile, after the treatment was implemented in the classroom, the result of the open-ended questionnaire indicated that $100 \%$ of the students gave positive response toward learning by stating they were happy doing activities in the classroom.

Table 13 The Summary of the Impact of Problem-Based Learning Towards Students' English Productive Skills

\begin{tabular}{|c|c|c|c|c|}
\hline NO & \multirow{2}{*}{ Impact on } & \multicolumn{2}{|c|}{ Mean Score } & $\begin{array}{c}\text { Analysis } \\
\text { Result } \\
\text { (Sig.) }\end{array}$ \\
\cline { 3 - 4 } 1. & $\begin{array}{c}\text { Students' } \\
\text { Attitude } \\
\text { towards ELL } \\
2 .\end{array}$ & $\begin{array}{c}\text { Treatment } \\
\text { Treatment }\end{array}$ & .000 \\
\hline $\begin{array}{c}\text { English } \\
\text { Productive } \\
\text { Skills. }\end{array}$ & Pre-Test & Post Test & \\
\hline & $\begin{array}{c}\text { a. Writing } \\
\text { Skill }\end{array}$ & 72.19 & 80.67 .39 & .000 \\
\hline & $\begin{array}{c}\text { b. Speaking } \\
\text { Skill }\end{array}$ & 76.6 & 81.04 & .000 \\
\hline
\end{tabular}

In addition, to provide complete information about the general result of the impact of Problem-Based Learning on English Language Learning, the researcher presents table 13. Based on the result of the data, Problem-Based Learning was proved to have a significant impact both in students' English productive skills and attitude. It can be seen in the following table. The table 13s shows there is an impact of ProblemBased Learning towards students' attitude and English productive skills. The significant impact was showed by both of the result of students' attitude towards English language learning and students' productive skills on its each pre-test and post-test $($ sig. $=.000)$. 
From the findings above it was found that Problem-Based Learning is a process of learning which demands students' responsibility towards their own education process. Students are working collaboratively in doing the task given. The sense of authentic and meaningful context of learning is also presented in the Problem-Based Learning and students are given chance to have hands-on experience. Significant difference was found on both students' speaking skill and writing skill after its implementation. Problem-Based Learning also brought positive enhancement on students' overall language skills including speaking and writing skill, with also the improvements on students' practice skills such as teamwork, decision-making and problem-solving skills.

Problem-Based Learning was able to increase students' enthusiasm for learning. When the children are excited and enthusiastic about what they are learning, they often get more involved in the subject, the level of anxiety is reduced and then expand their interest to other materials. Enthusiastic students tend to retain what they learn, not to forget it as soon as they have passed the test.

Problem-Based Learning revealed to enhance students' learning ability in self-directed and collaborative learning. The facts found that students really attempted to learn together in form of group work but also had chance to take initiative and responsibility for learning. While working in a group, the students did some activities such as asking one another for information, evaluating one another's ideas, monitoring one another's work and actively interacted by sharing idea, etc. Individually, each of the student were given chance to select and manage their own work. These activities were done in order to maximize their own and each other's learning.

\section{CONCLUSION}

This study has provided an empirical evidence that Problem-Based Learning has significant impacts on students' productive skill and attitude. This conclusion can be drawn by looking at the improvement of student mean score during the pre-test and post-test. The attitude of students toward English Language Learning has also changed after given the treatment of Problem-Based Learning, it can be seen from the result of the questionnaire given. The significant impacts given by Problem-Based Learning instruction indicate that this approach can be taken into consideration by the teacher as an approach to be implemented in the classroom in general, or in EFL classes in particular.. Besides giving positive impact on students skill and attitude, Problem-Based Learning has also been observed to build learner critical thinking, self directed learning, and problem solving skill.

\section{REFERENCES}

[1] Barrows, H.S. (1985). Howto design a problem-based curriculumfor the preclinical years. NY: Springer.
[2] Barrows, H. S. (1986). Problem-Based Learning in medicine and beyond: A brief overview. In L. Wilkerson \& W. Gijselaers (Eds.), Bringing Problem-Based Learning to higher education: Theory and practice. New Directions for Teaching and Learning Series, No. 68 (pp. 3-11). San Francisco: Jossey-Bass.

[3] Hmelo-Silver, C.E. (2004). Problem-Based Learning: What and How Do Students Learn?.Educational Psychology Review, 16(3)[Online]https://www.researchgate.net/publication/226053277_Pro blem-Based_Learning_What_and_How_Do_Students_Learn[Accessed on 6 November 2016]

[4] Coffin, P. (2013). The impact of the implementation of the PBL for EFL interdisciplinary study in a local Thai context. The 4th International Research Symposium on Problem-Based Learning (IRSPBL).[Online] Available from http://tree.utm.my/wp-content/uploads/2013/11/TheImpact-of-the-Implementation-of-the-PBL-for-EFL-InterdisciplinaryStudy-in-a-Local-Thai-Context-.pdf [Accessed on 1st November 2016]

[5] Weimer, M. (2009). Problem-Based Learning: benefits and risk in faculty focus: effective teaching strategies. [Online] Available fromhttp://www.facultyfocus.com.articles/effective-teachingstrategies/problem-based-learning-benefits-and-risk/[Accessed on 9th November 2016]

[6] Abidin, Mohamad JafreZainol. 2012. EFL Sudents' Attitudes towards Learning English Language: The Case of Libyan Secondary School Students. The Canadian Center of Science and Education (CCSE) Journal,8(2). [Online] Available from http://dx.doi.org/10.5539/ass.v8n2p119 [Accessed on 4thNovember 2016]

[7] Othman, N., \& Shah, M.I.A. (2013). Problem-based learning in the English language classroom. English Language Teaching. 6(3), ISSN 1916-4742, E-ISSN 1916-4750. [Online] Available from http://dx.doi.org/10.5539/elt.v6n3p125 [Accessed on $11^{\text {th }}$ November 2016]

[8] Torp, L and Sage, S. (2002). Problems as possibilities: Project-Based Learning for K-16 education (second edition). [Online] Available from: http://en.bookfi.org. [Accessed on 9th November 2016]

[9] Creswell, J. \& Plano Clark, V. (2007). Designing and Conducting Mixed Methods Research. Thousand Oak, California: Sage Publication.

[10] Miles, M. B., \& Huberman, A. M. (1984). Qualitative data analysis. Beverly Hills. 